Cox, W. A., A. C. Schwarzer, and B. Tornwall. 2019. Postfledging survival of the Worthington's Marsh Wren (Cistothorus palustris griseus). Avian Conservation and Ecology 14(2):19. https://doi.org/10.5751/ACE-01472-140219

Copyright (C) 2019 by the author(s). Published here under license by the Resilience Alliance.

Research Paper

\title{
Postfledging survival of the Worthington's Marsh Wren (Cistothorus palustris griseus)
}

W. Andrew Cox ${ }^{1}$, Amy C. Schwarzer ${ }^{1}$ and Brett Tornwall ${ }^{1}$

${ }^{1}$ Fish and Wildlife Research Institute, Florida Fish and Wildlife Conservation Commission

\begin{abstract}
The postfledging period of a passerine bird's life is increasingly recognized as an understudied component of songbird conservation, because the habitat needs of fledglings can differ from nesting adults and survivorship during this period can substantially affect population growth rates. We studied postfledging survival of the Worthington's Marsh Wren (Cistothorus palustris griseus), a state-listed salt marsh songbird subspecies in northeastern Florida, USA, during 2016-2017. Postfledging survival was low during the first $21 \mathrm{~d}$ following fledging for the cohort of tracked birds $(0.10 ; 95 \%$ confidence interval: $0.01,0.37)$. The top a priori model indicated that heavier birds at the time of tagging exhibited greater survival than lighter birds, and birds from larger broods had greater survival than birds from smaller broods. Other covariates not in the top model that also influenced survival included the amount of tall-form smooth cordgrass (Spartina alterniflora) within the natal patch, which positively influenced survival, and the amount of black needlerush (Juncus roemerianus) within the natal patch, which negatively affected survival. The low rates of postfledging survival combined with low rates of nest survival reported elsewhere indicate that Worthington's Marsh Wrens in northeastern Florida require continued protection and warrant further research into management and restoration activities that will improve their habitat.
\end{abstract}

\section{Survie suivant l'envol du nid chez le Troglodyte des marais de Worthington (Cistothorus palustris griseus)}

RÉSUMÉ. La période suivant l'envol du nid dans la vie d'un passereau est de plus en plus reconnue comme une composante sousétudiée de la conservation des oiseaux chanteurs, parce que les besoins en matière d'habitat des jeunes suivant l'envol sont peut-être différents de ceux des adultes nicheurs et la survie durant cette période peut grandement affecter les taux de croissance des populations. Nous avons étudié la survie suivant l'envol du nid du Troglodyte des marais de Worthington (Cistothorus palustris griseus), une sousespèce de passereau de marais salés désignée au niveau de l'État dans le nord-est de la Floride, États-Unis, en 2016 et 2017 . Le taux de survie suivant l'envol du nid était faible durant les 21 jours suivant l'envol chez la cohorte d'oiseaux suivis $(0,10$; intervalle de confiance à $95 \%$ : 0,01-0,37). Le meilleur modèle a priori a indiqué que les oiseaux plus lourds au moment du marquage avaient une meilleure survie que les oiseaux plus légers, et les oiseaux provenant de couvées plus nombreuses avaient un meilleur taux de survie que les oiseaux issus de couvées moins nombreuses. Les autres covariables ayant un effet sur la survie, mais non inclues dans le meilleur modèle a priori, comprenaient la quantité de spartine alterniflore (Spartina alterniflora) de forme haute dans la parcelle abritant le nid, qui avait un effet positif sur la survie, et la quantité de jonc (Juncus roemerianus) dans la parcelle abritant le nid, qui avait un effet négatif sur la survie. Le faible taux de survie des jeunes suivant leur envol, combiné aux faibles taux de survie des nids rapportés dans d'autres études, indiquent que les Troglodytes des marais de Worthington du nord-est de la Floride requièrent une protection continue et davantage de recherches sur les activités d'aménagement et de restauration qui amélioreraient leur habitat.

Key Words: Cistothorus palustris griseus; demography; Marsh Wren; postfledging survival; salt marsh

\section{INTRODUCTION}

Effective wildlife management requires consideration of the full life cycle of a species of interest and should address habitat needs across multiple life stages. For example, sea turtle management traditionally focused on nests and newly hatched young until population models identified mature adult survival as the factor most relevant to positive population growth (Crouse et al. 1987). Similarly, low rates of Cheetah (Acinonyx jubatus) cub survival suggested that management should focus on reducing cub predation until population modeling highlighted the need to carefully contemplate trade-offs between productivity and adult survival (Crooks et al. 1998). These studies and many others highlight the need to expand our understanding of the habitat needs of wildlife beyond what has traditionally been studied (Marra et al. 2015).

For relatively short-lived animals, such as North American songbirds, management has often used nest survival as a proxy for breeding habitat quality because it is an important demographic parameter that can drive population growth (Donovan and Thompson 2001). However, the postfledging life stage, i.e., the period after young birds leave the nest but before they disperse and/or migrate, is increasingly recognized as an understudied but critically important component of songbird conservation (Cox et al. 2014, Streby et al. 2014). Fledgling birds often use different habitats than nesting adults (Anders et al. 1998, Vitz and Rodewald 2006, Streby et al. 2015b), and there can be 
fitness consequences associated with poor postfledging habitat. For example, Spotted Towhee (Pipilo maculatus) fecundity was greatest in nonoptimal nesting habitat because the highest quality nesting habitat was associated with the lowest rates of postfledging survival (Shipley et al. 2013). More generally, rates of postfledging survival are sometimes too low to support positive population growth (Rush and Stuchbury 2008, Balogh et al. 2011, Hovick et al. 2011). A review of the literature (Cox et al. 2014) suggests that postfledging survival is often correlated to habitat conditions and is thus a demographic parameter that should be incorporated into conservation planning.

We studied postfledging survival of the Worthington's Marsh Wren (Cistothorus palustris griseus) in northeastern Florida, USA. The Worthington's Marsh Wren (hereafter Marsh Wren) is an obligate coastal subspecies that resides in salt marshes on the Atlantic coast from Florida north to South Carolina (Kroodsma and Verner 2013). The Marsh Wren's range in Florida has contracted by $>80 \%$ from its historical extent (Kale 1996) and now exists only north of the St. John's River in Duval and Nassau counties (NeSmith and Jue 2003) in marshes dominated by tall and short forms of smooth cordgrass (Spartina alterniflora; hereafter tall or short cordgrass) and black needlerush (Juncus roemerianus; hereafter needlerush). Florida's salt marshes are characterized as poor and in declining condition (Florida Fish and Wildlife Conservation Commission [FWC] 2012), and the Marsh Wren's range contraction, small population size, and restricted distribution led to the species being listed as threatened in the state (FWC 2016). Florida's recovery plan for Marsh Wrens (FWC 2013) describes the need for habitat-specific demographic data to provide insight on the range contraction and concomitant population decline.

We assessed four hypotheses explaining variation in postfledging survival. First, we hypothesized that conditions in the nest (nestling weight and brood size) would influence survival, with larger chicks from smaller broods exhibiting greater survival (sensu Suedkamp Wells et al. 2007). Second, we hypothesized that heavy rainfall from afternoon storms would reduce survival of fledglings via direct mortality, as has been observed for nestling passerines during severe weather events (Cox et al. 2013, Hightower et al. 2018). Third, we hypothesized that tide intensity would influence survival. High tides can cause substantial nest failure (Bayard and Elphick 2011, Hunter 2017), and we predicted that high water levels would similarly reduce fledgling survival either directly by drowning young birds, which were only modestly flight capable at fledging, or indirectly by concentrating terrestrial predators such as rice rats (Oryzomys palustris), mink (Neovison vison), and snakes, e.g., corn snake (Pantherophis guttatus) and cottonmouth (Agkistrodon piscivorus), into the highest areas of the marsh (Cox et al., in press). Finally, we hypothesized that vegetation within the habitat patch where the nest was located and where young birds resided immediately postfledging would influence survival. Specifically, we predicted that survival would be greater in patches farther from upland-salt marsh interfaces because Marsh Wrens tend to prefer patches farther from edges (Nuse et al. 2015), perhaps to avoid terrestrial predators. We also predicted that greater amounts of needlerush would result in reduced survival because rice rats prefer this vegetation and are a likely predator of eggs and nestlings (Post 1981). Finally, we predicted that greater amounts of tall cordgrass would increase survival by providing a greater area of dense, tall foliage to hide from predators.

\section{METHODS}

\section{Study area and species}

We located and monitored Marsh Wren nests from early April to mid-August in 2016 and 2017 at 5 sites on the Nassau River and Clapboard Creek in Duval and Nassau counties in northeastern Florida, just south of the Georgia border (Fig. 1). The climate of northeastern Florida is characterized by hot and humid summers, substantial late spring and summer rainfall, and mild winters with temperatures infrequently dropping below freezing. The average tidal range in northeastern Florida is $0-1.5 \mathrm{~m}$, with tides $>2.0 \mathrm{~m}$ during spring tides. Two of the 5 sites flooded, i.e., water covered the highest ground within a study site, on normal high tides, whereas all 5 flooded on spring tides to varying degrees, with water depths not typically exceeding $\sim 30 \mathrm{~cm}$. Three of 5 sites were dominated by cordgrass, which exhibited a sharp transition in height from $\geq 1 \mathrm{~m}$ (hereafter tall cordgrass) within several meters of a creek or river to $<50 \mathrm{~cm}$ (hereafter short cordgrass) in the lower elevation flats that composed much of the marsh. The southwestern site was dominated by needlerush, with small amounts of cordgrass interspersed throughout. All sites also had smaller patches of succulents such as glasswort (Salicornia depressa), salt wort (Batis maritima), and sea ox-eye (Borrichia frutescens).

Fig. 1. Five study sites in a study of Worthington's Marsh Wren postfledging survival in northeastern Florida, 2016-2017.

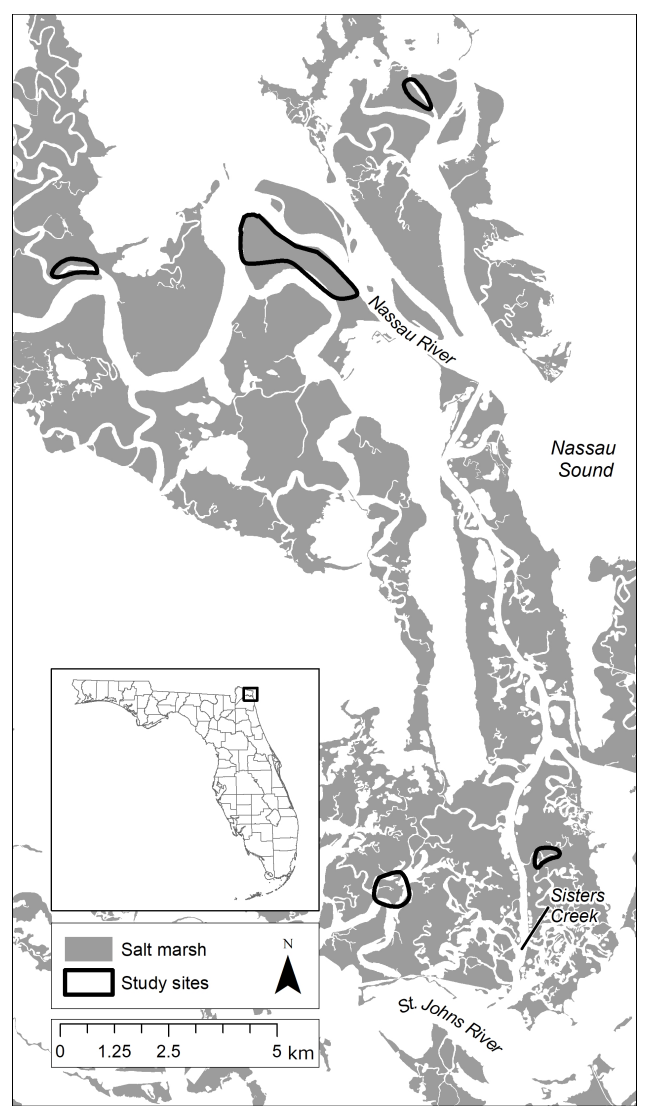


Marsh Wren nesting territories were usually quite small (often < 82-155 $\mathrm{m}^{2}$; Kale 1965) and densely packed along the edges of the river and tidal creeks within the salt marsh. Adults spent much of their time within nesting territories but also ranged out of them into short cordgrass flats to forage. Territories usually had 1 active nest and multiple dummy nests, which may serve to deter predators (Leonard and Picman 1987), attract mates (Verner and Engelsen 1970), or shelter newly fledged young (Chicalo et al. 2019). Nests were domed, usually woven into multiple blades of needlerush or tall cordgrass between 1 and $2 \mathrm{~m}$ high, and tended to occur in higher elevation areas along the creek edges where vegetation was typically tallest. Nests did not occur in short cordgrass. The median clutch size in northeastern Florida was 4 (range, $1-6 ; n=489$ ), the average incubation period was $14 \mathrm{~d}$ (range, $11-17 \mathrm{~d} ; n=60$ ), and the average nestling period was $13 \mathrm{~d}$ (range, 10-16 d; $n=50$; Schwarzer, unpublished manuscript). The breeding season began in late March and lasted through August.

\section{Field methods and habitat measurements}

We searched for nests using established protocols (Martin and Geupel 1993) and recorded nest locations upon discovery using a handheld GPS unit. We typically monitored nests every $7 \mathrm{~d}$ to reduce disturbance to nesting birds and to nearby vegetation, but we adjusted the schedule as needed to affix transmitters to nestlings just prior to fledging. During each nest check, we recorded the date, time, and number of eggs and/or nestlings present. We aged nestlings based on known hatch dates or by using a photographic aging guide we developed using known-age nestlings. Because birds sometimes returned to their natal nest after fledging, we defined the fledging date as the 1st day we observed a tagged bird or its nestmates outside the nest.

In 2016, we affixed 16 radio-transmitter tags (Lotek Pip Ag 337) to Marsh Wren nestlings using a modified leg-loop harness design as described in Streby et al. (2015a). We reduced the standard pulse rate and pulse length so transmitters could approach their maximum life of $23 \mathrm{~d}$. Preharness transmitter weights averaged $0.352 \mathrm{~g}$ (range, $0.34-0.36 \mathrm{~g}$ ). Transmitter weights following harness attachment and trimming the antenna to $5-9 \mathrm{~cm}$ in length averaged $0.369 \mathrm{~g}$ (range, 0.36-0.39). Birds observed during days 10-15 of the nestling period were consistently smaller than described by Kale (1965). Therefore, we only affixed transmitters to the largest nestlings we encountered. The average weight of nestlings at tagging was $9.41 \mathrm{~g}$ (range, 9.1-10.1 g; $n=16$ ); no tag exceeded $4 \%$ of a bird's body weight.

In 2017, we switched to a smaller radio transmitter (Advanced Telemetry Systems A2412) so we could tag smaller nestlings and obtain a more representative sample of birds. We affixed 34 transmitters to Marsh Wren nestlings using the same modified leg-loop harness used in 2016. We reduced the pulse rate and pulse length so transmitters could approach their maximum life of 21 d. Preharness transmitter weights averaged $0.25 \mathrm{~g}$ (range, $0.24-0.25 \mathrm{~g}$ ), and postharness attachment weights averaged 0.27 $\mathrm{g}$ (range, 0.24-0.29). We affixed transmitters to nestlings that averaged $8.9 \mathrm{~g}$ (range, 7.0-10.4 g); no tags exceeded $3.5 \%$ of a bird's body weight. In both years, our goal was to select only 1 nestling per nest to avoid potential nonindependence of tracked birds, but rates of nest failure were high ( $90 \%$; Cox et al., in press), so we tagged 2 nestlings in 8 of the nests to ensure all transmitters were deployed. All birds also received 1 color band to help confirm their fates in the case of lost or malfunctioning transmitters.
We tracked birds daily by foot (unless storms prevented access) using 3-element Yagi antennas and Lotek Biotracker receivers. The effective range of the transmitters was approximately $500 \mathrm{~m}$ in 2016 and approximately $250 \mathrm{~m}$ in 2017 because the smaller transmitters had a reduced range. We recorded fledgling locations with GPS units and typically used offsets and flagging to avoid directly interacting with the tagged birds and damaging the habitat in which they resided. We created a tracking schedule that broke each day into five 3-h time periods and four tide levels (low, midfalling, midrising, and high) to ensure that our tracking data were not biased by diel or tidal influences on fledgling behavior. The threat of storms frequently prevented us from tracking in the $3 \mathrm{PM}$ to $6 \mathrm{PM}$ and $6 \mathrm{PM}$ to dusk time blocks $(n=43$ total tracking events), but we had nearly equal effort among the dawn to 9 AM $(n=105), 9 \mathrm{AM}$ to noon $(n=110)$, and noon to $3 \mathrm{PM}(n=90)$ blocks. Similarly, it was difficult to track birds at low tides $(n=$ 38) when water levels were too low to access sites on most days, but we had a more representative sample of midrising $(n=92)$, high $(n=98)$, and midfalling $(n=120)$ tides.

We coded the final fate of a bird as alive if it survived the maximum life span of the smaller transmitter $(21 \mathrm{~d})$, if it was resighted after transmitter failure, or if its behavior was consistent with permanent dispersal. We assumed birds had dispersed permanently if we observed a movement $>100 \mathrm{~m}$ prior to a bird's disappearance. We coded the final fate of a bird as dead if we found direct evidence of its mortality, which infrequently occurred because high tides washed evidence away. As such, we also considered birds to be dead if adult birds were present on the natal territory but not defensive, if the tagged bird could not be relocated via 3 subsequent tracking/resighting efforts, and if it was too early ( $<10 \mathrm{~d}$ based on our observations) in the postfledging period for a fledgling to disperse or achieve independence. We right-censored birds with confirmed radiotransmitter failure or when their fate was unknown following Pollock et al. (1989), who suggest that it is appropriate when there is no reason to suspect that mortality rates differ between censored and uncensored birds.

We did not incorporate into the study any vegetation measurements at specific points used by fledglings because it was not possible to know the location of mortality events, i.e., even when transmitters were recovered, we did not know where the bird actually died, and thus it was not possible to integrate pointlevel vegetation into a survival analysis. Instead, shortly after the nestlings fledged, we took an ocular estimate of the proportion of habitat that was tall cordgrass, short cordgrass, and needlerush within a $50 \mathrm{~m}$ radius of the nest. We selected a $50 \mathrm{~m}$ radius based on prior observations of adult birds with active nests and recent fledglings, which indicated that family groups tended to stay in the natal territory in the first 1-2 wk postfledging (Schwarzer, personal observation). A post hoc examination of the data confirmed our observations; only 2 fledglings moved $>50 \mathrm{~m}$ within the 1st wk of fledging (one of which soon returned to its natal territory), and fledglings were frequently observed using the natal and nearby dummy nests for shelter (Chicalo et al. 2019).

We obtained tide data from the National Oceanic and Atmospheric Administration (NOAA) tide station 8720218 in Mayport, Florida (NOAA 2018), and weather data from the NOAA weather station (station USW00003853 in Mayport and station US1FLNS0014 at the Fernandina Beach airport; NOAA, 
National Centers for Environmental Information 2018) nearest each site. The tide station was 3-21 km from each site, the Mayport weather station was $3-5 \mathrm{~km}$ from the southern sites, and the Fernandina Beach Airport station was 3-11 km from the northern sites. We determined distance to upland edge by calculating the distance from the nest site to the nearest boundary for a land cover class that was not salt marsh or open water using the Florida Cooperative Land Cover Map (Version 3.2, October 2016 [FWC and Florida Natural Areas Inventory 2016]).

\section{Analysis}

We used a logistic exposure model to predict daily fledgling survival probability as a function of covariates while controlling for varying monitoring interval length (Shaffer 2004). To fit models, we used the $\mathrm{R}$ programing environment ( $\mathrm{R}$ Development Core Team 2017) and the glm function with a binomial response distribution and a custom link function per Shaffer (2004). We computed a variance inflation factor for each potential covariate and visually inspected covariates for multicollinearity by creating scatter plots (Fox and Monette 1992). All variance inflation factors were $<3$, and the absolute value of correlations between variables was $<0.50$, which indicated a lack of multicollinearity.

We performed a three-step model selection process that allowed us to control for temporal factors that might influence postfledging survival, assess support for each of our a priori hypotheses, and explore the data to ensure we were aware of the full suite of covariates that influenced postfledging survival. To control for temporal factors, we created five models (age, quadratic age, date, quadratic date, and a global model; Table 1) and evaluated their support within an information-theoretic framework using corrected Akaike's information criterion $\left(\mathrm{AIC}_{c}\right)$, with relative weights $(\triangle \mathrm{AIC})$ also calculated for each model (Burnham and Anderson 2002). We did not account for model selection uncertainty in this step because we were interested in accounting for as much temporal variation as parsimoniously as possible and instead included covariates from the best temporal model to create our four a priori models representing our previously described hypotheses (Table 2). We included a fifth a priori model in the candidate set with a fixed effect for study site to assess whether there were inherent differences in habitat quality across sites that were not captured by our vegetation measurements. We considered models within four AIC units of the top-ranked model to be competitive. We explored the inclusion of a random effect for territory ID to account for a lack of independence between fledglings from the same nest, but a likelihood ratio test indicated that the random effect did not improve the top model $\left(\chi^{2}=2.13, P=0.14\right)$, so all models in the candidate set included only fixed effects. Finally, we performed an analysis using backward AIC-based stepwise regression with all covariates via the stepAIC function in the MASS $r$ package (Venables and Ripley 2002) but did not include it in the model selection process with the a priori hypotheses. We evaluated all retained models for goodness of fit using the Hosmer and Lemeshow goodness-of-fit test via the hoslem.test function in the ResourceSelection R package (Lele et al. 2017) with $\alpha=0.05$.

We generated figures displaying predicted survival as a function of a single covariate with the other covariates set to the mean value using the predict.glm function and the top fitted model per $\mathrm{AIC}_{c}$. To ensure that our results were comparable to many past studies, we produced an empirically derived estimate of survival from our sample of tagged birds that represents survivorship of the cohort we tracked. We also produced model-based predictions that represent survival for the population of interest rather than for our sample of birds (Shaffer and Thompson 2007), by using age-specific daily survival rates with covariates held at their mean values. We produced both estimates for the first 10 and $21 \mathrm{~d}$ postfledging.

Table 1. Model structure and model selection results for candidate models describing temporal variation in postfledging survival of Worthington's Marsh Wrens in northeastern Florida, 2016-2017. Results are from 50 radio-tracked birds. The quadratic age model was carried forward into the second set of models because it was the best fit for the 46 birds for which there were habitat measurements.

\begin{tabular}{llllll}
\hline \hline Model Name & Model Structure & $K^{\dagger}$ & $\mathrm{AIC}_{c}^{*}$ & $\Delta \mathrm{AIC}_{c}^{\S}$ & $w_{i}^{\dagger}$ \\
\hline Null & & 1 & 222.85 & 0.00 & 0.28 \\
Ordinal date & Date & 2 & 223.44 & 0.59 & 0.21 \\
Quadratic age & Age + age $^{2}$ & 3 & 223.68 & 0.82 & 0.18 \\
Quadratic date & Date + date $^{2}$ & 3 & 224.21 & 1.36 & 0.14 \\
Age & Age & 2 & 224.75 & 1.90 & 0.11 \\
Global & Age + age $^{2}+$ date $^{+}+$date $^{2}$ & 5 & 225.18 & 2.33 & 0.08 \\
\hline
\end{tabular}

${ }^{\dagger}$ Number of parameters in the model.

${ }^{\ddagger}$ Akaike information criterion (AIC) corrected for small sample sizes.

${ }^{\S}$ The difference between the current and top-ranked model's AIC score.

'Weight of evidence supporting the model.

Table 2. Model structure and model selection results for a priori candidate models describing variation in postfledging survival of Worthington's Marsh Wrens in northeastern Florida, 2016-2017. All models include covariates from the quadratic age temporal model. The best stepwise model is included in the table for comparison but was not included in the model selection analysis. Tall or short cordgrass: Spartina alterniflora; needlerush: Juncus roemerianus.

\begin{tabular}{llcccc}
\hline \hline $\begin{array}{l}\text { Model } \\
\text { Name }\end{array}$ & Model Structure & $K^{\dagger}$ & $\mathrm{AIC}_{c}^{\ddagger}$ & $\Delta \mathrm{AIC}_{c}^{\S}$ & $w_{i}^{l}$ \\
\hline Intrinsic & Weight + brood size & 5 & 195.50 & 0.00 & 0.98 \\
Weather & Maximum daily precipitation & 4 & 205.57 & 10.06 & 0.01 \\
Site & Study site & 7 & 205.88 & 10.38 & 0.01 \\
Tide & Tide & 4 & 206.03 & 10.53 & 0.00 \\
Null & & 3 & 206.26 & 10.76 & 0.00 \\
Habitat & Distance to edge + patch tall & 7 & 210.82 & 15.31 & 0.00 \\
& cordgrass + patch short & & & & \\
& cordgrass + patch needlerush & & & & \\
Best & Weight + brood size + patch & 7 & 191.57 & & \\
stepwise & tall cordgrass + patch & & & & \\
& needlerush & & & & \\
\hline
\end{tabular}

Number of parameters in the model.

${ }^{\star}$ Akaike information criterion (AIC) corrected for small sample sizes.

${ }^{\S}$ The difference between the current and top-ranked model's AIC score. 'Weight of evidence supporting the model.

\section{RESULTS}

We tagged 50 nestling Marsh Wrens from 42 nests during 2016-2017. The median age of fledglings at departure from the nest was $13 \mathrm{~d}$ (range, 10-16 d). We conducted 305 total tracking 
events that covered 334 exposure days. We failed to record nest patch vegetation measurements for 4 birds that all died within 2 $\mathrm{d}$ of fledging, and we excluded them from the analysis that included habitat measurements, which resulted in 328 analyzed exposure days from 46 fledglings.

Ten of $46(22 \%)$ tagged birds survived until they dispersed $(n=$ 1) or their transmitter died ( 2 lasted $>21 \mathrm{~d}, 1$ lasted $14 \mathrm{~d}$, and 6 lasted $\leq 7 \mathrm{~d}$ following attachment). Thirty-six of $46(78 \%)$ tagged birds died before the end of the 21-d life span of the transmitters, with $34(94 \%)$ of those dying within $10 \mathrm{~d}$ of fledging. Twenty of the 36 dead birds were classified as such based on adult behavior and/or transmitter recovery. Six birds were classified as dead because adults were still aggressive, but only siblings of the tagged bird were resighted in 3 visits following the presumed mortality event. Four birds were obviously depredated: 1 bird was predated by a corn snake (Pantherophis guttatus), 1 was found partially eaten on top of a nest, 1 natal nest entrance was enlarged when fledglings were still using it after they initially fledged, and 1 transmitter was found with both leg-loop harnesses broken. A fifth bird may have been depredated; we found it in its natal nest $6 \mathrm{~d}$ postfledging (we previously confirmed it had left the nest), and it appeared to have been picked at by crabs. Four birds were not found the day following severe thunderstorms. Finally, 1 bird was found dead $21 \mathrm{~d}$ postfledging and had no obvious wounds or other signs to indicate the cause of death. Four birds had unknown fates and were right-censored from analyses: 1 dispersed $60 \mathrm{~m}$ at $7 \mathrm{~d}$ of age and then disappeared, 1 transmitter was found in the nest $2 \mathrm{~d}$ after fledging with no other signs of predation or of the adult birds, but we did not make a sufficient resighting effort to confirm death, and 2 birds were not seen again after their intermittently functional transmitters stopped working at 8 and $11 \mathrm{~d}$ postfledging.

The best temporal model for Marsh Wren postfledging survival for all 50 tagged birds was the null (Table 1), which indicated that no temporal covariates substantially influenced postfledging survival. However, the quadratic age model was best supported $\left(w_{i}=0.28\right)$ when the 4 birds that lacked habitat data were removed from the data set. As such, we carried the quadratic model forward to the next step in the analysis, but we interpret the null model as best supported with respect to the effects of temporal covariates on fledgling survival.

The intrinsic model was top ranked and carried nearly all model weight (Table 2). The Hosmer-Lemeshow goodness-of-fit test of the top model indicated that the observed and expected survival probabilities were not significantly different $(P=0.12)$. Predictions from the intrinsic model indicated that heavier nestlings and those from larger broods exhibited greater postfledgling survival (Fig. $2: \beta_{\text {weight }}=0.97 \pm 0.30$ standard error $\left.[\mathrm{SE}], \beta_{\text {brood }}=0.43 \pm 0.25 \mathrm{SE}\right)$.

In 2016, we tagged only larger fledglings because the fledglings were smaller than we expected. As such, we performed a post hoc assessment to determine whether the substantial positive correlation between body weight and survival might have been confounded with a possible year effect, i.e., the increased survival of larger fledglings may reflect better survival in 2016 versus 2017, by evaluating all models with only 2016 data and then with only 2017 data. In both cases, the top a priori model remained the same, and parameter estimates were similar to the combined data set. Daily survival probabilities for 2016 birds were greater than for 2017 birds, but this was expected given the strong effect fledgling weight appears to have on survival probability.

Fig. 2. Model-based predictions of Worthington's Marsh Wren fledgling daily survival in northeastern Florida, 2016-2017, as a function of weight at tagging (A) and brood size (B) from the top-ranked a priori model. All other covariates were held at their mean values. Dashed lines and bars indicate 95\% confidence intervals. Numbers above bars in panel B indicate the sample size of birds tracked from each brood size.

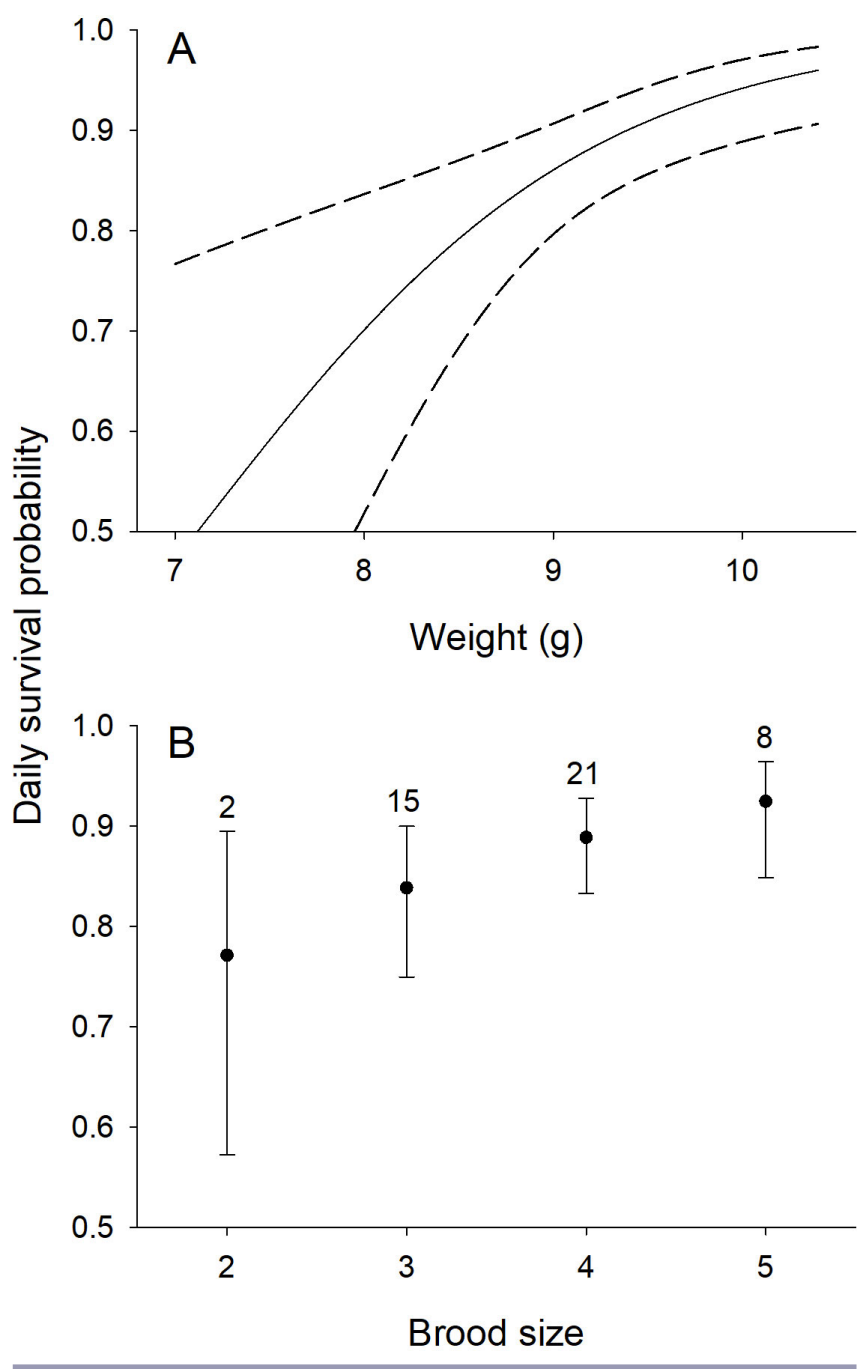

The probability of a bird surviving $10 \mathrm{~d}$ postfledging as empirically derived from the data set was $0.34(95 \%$ confidence interval $[C I]: 0.10,0.61)$, and probability of survival was $0.10(95 \%$ CI: $0.01,0.37$ ) for the entire $21-\mathrm{d}$ period. Model-based estimates generated with age-specific daily survival rates and mean values for body weight and brood size were 0.21 (95\% CI: 0.07, 0.40) for the first $10 \mathrm{~d}$ postfledging and $0.03(95 \% \mathrm{CI}: 0.0,0.19)$ for the first $21 \mathrm{~d}$.

The best stepwise model (Table 2$)$ included nestling weight $\left(\beta_{\text {weight }}\right.$ $=1.21 \pm 0.32 \mathrm{SE})$, brood size $\left(\beta_{\text {brood }}=0.78 \pm 0.31 \mathrm{SE}\right)$, and percent 
tall cordgrass $\left(\beta_{\text {cordgrass }}=0.05 \pm 0.03 \mathrm{SE}\right)$ and percent needlerush $\left(\beta_{\text {needlerush }}=-0.08 \pm 0.03 \mathrm{SE}\right)$. The Hosmer-Lemeshow goodnessof-fit test of the model indicated that the observed and expected survival probabilities were not significantly different $(P=0.81)$. Predictions from the model indicated that increased daily survival was associated with increased tall cordgrass and decreased needlerush in the territory patch (Fig. 3).

Fig. 3. Model-based predictions of Worthington's Marsh Wren fledgling daily survival in northeastern Florida, 2016-2017, as a function of percent tall cordgrass (Spartina alterniflora; A) and needlerush (Juncus roemerianus; B) from a stepwise model. All other covariates were held at their mean values. Dashed lines indicate $95 \%$ confidence intervals.

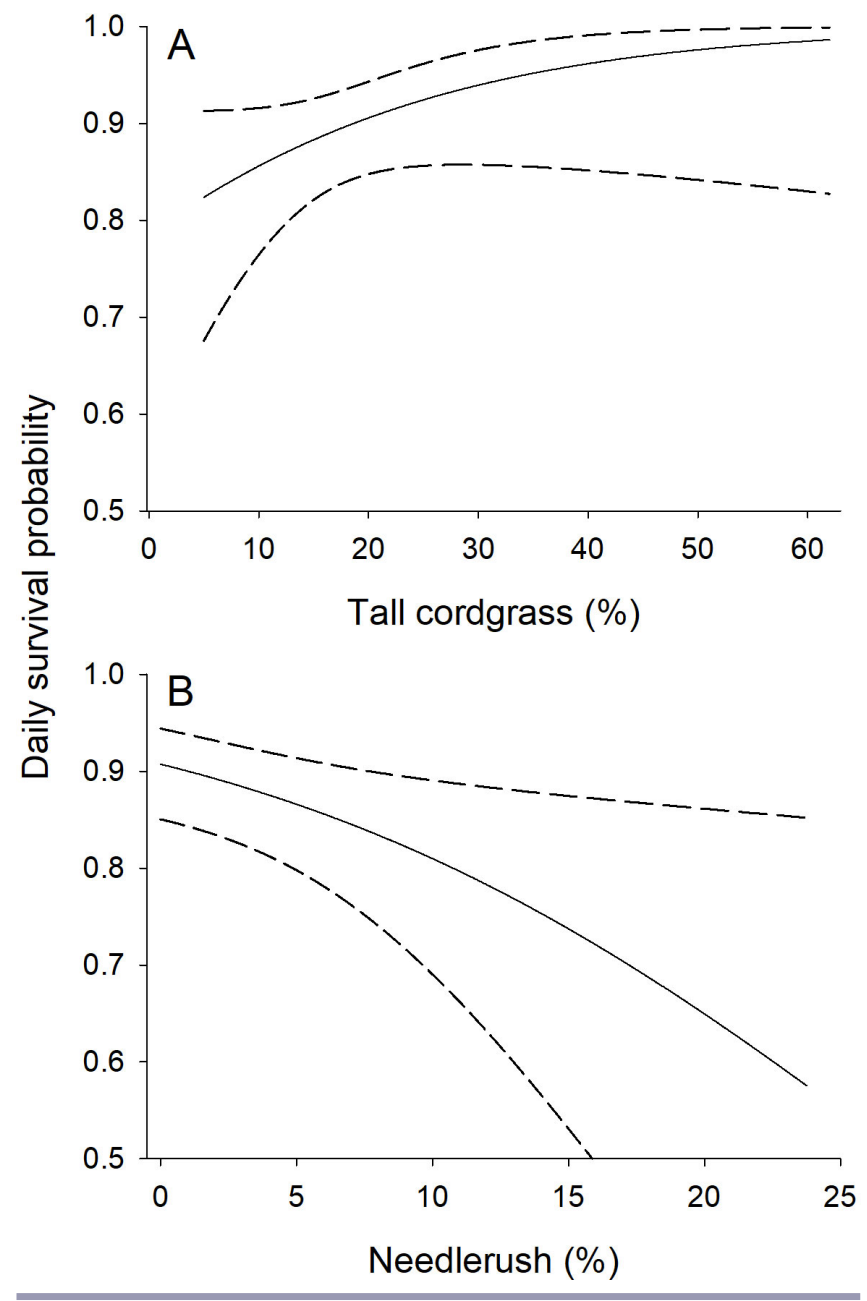

\section{DISCUSSION}

We assessed the postfledging survival of Marsh Wrens to better understand factors influencing the population trends of the species in northeastern Florida. Postfledging survival rates for the first $21 \mathrm{~d}$ out of the nest were among the lowest reported for passerines in the literature (see Cox et al. 2014 for a recent summary). The top a priori model, which received nearly all support within an information-theoretic framework, described traits of birds, i.e., weight and brood size, that are largely outside the direct control of land managers. Nevertheless, managers may indirectly influence such traits, and the stepwise model suggested that habitat features, e.g., tall and short cordgrass, which managers can more directly control, also influenced survival.

Age is frequently a good predictor of postfledging survival for passerines (Cox et al. 2014), and young birds almost always exhibit low initial postfledging survival followed by increased survivorship as they grow and learn how to interact with their environment (e.g., Ausprey and Rodewald 2011, Balogh et al. 2011, Eng et al. 2011). By contrast, age did not influence Marsh Wren fledgling survival. This may indicate that newly fledged birds benefit from the use of dummy nests for shelter (Chicalo et al. 2019) because initial survivorship, when mortality risks are usually greatest, was not lower than later in the postfledgling period. In addition, the presumable loss of access to dummy nests as birds dispersed, which began approximately at $10 \mathrm{~d}$ of age, as well as reduced feeding from adult birds that rapidly renest (5-14 d post fledging; Kroodsma and Verner 2013), may have offset any advantages young birds gained with increased experience out of the nest. Alternatively, the low overall survivorship we observed may indicate that threats to young birds are so substantial that they simply fail to learn how to avoid common causes of mortality during their first $3 \mathrm{wk}$ out of the nest. More study is needed to understand why survivorship did not increase with age as is typically observed.

The weight of a Marsh Wren nestling at the time it was tagged was also a strong predictor of postfledging survival, with the smallest nestlings associated with extremely high mortality rates. This is concordant with many studies that demonstrate that the body size of young animals is often positively correlated with survival (see Magrath [1991] for a review of previous avian studies). A combination of genetic and environmental factors contributes to the size of offspring (e.g., Gebhardt-Henrich and Van Noordwijk 1991), with resource availability most relevant to the conservation of Marsh Wrens. Adult birds can produce larger chicks when food availability is high (Wilkin et al. 2009), and it may be that the largest chicks have high-quality parents and/or exist on high-quality territories. Indeed, larger brood sizes, itself an indication of plentiful food availability (King 1973), was also associated with greater survival rates. Although we lack data sufficient for a rigorous comparison, nestlings at one of our sites appeared to develop substantially faster than at any other site (Schwarzer and Cox, personal observation). Comparing food resources across territories and sites could shed additional light on what differentiates low- and high-quality salt marsh habitat for breeding Marsh Wrens.

Two prominent vegetative features of the salt marsh were correlated with survival in the manner we predicted, with greater postfledgling survival associated with more tall cordgrass and less needlerush within a natal patch. Measurements of the two vegetation types were not correlated, as open water and other vegetation types also comprised the natal patch, which suggests that they independently influenced survival. Tall cordgrass nearly always occurred in narrow strips at our sites, with open water or tidal creeks abutting the exterior side of the strip, and sparse, short cordgrass abutting the interior side. Open water is obviously not Marsh Wren habitat, and the short cordgrass was too sparse to offer cover from predators or the heat of the direct sun for a young 
bird, so it is intuitive that more tall cordgrass offers young Marsh Wrens more space in which to safely reside. In addition, both adult and young birds primarily eat terrestrial insects, e.g., grasshoppers and ants, that appeared to be substantially more abundant in tall cordgrass stands (Schwarzer, personal observation), though more study is needed to quantify this. Needlerush stands would seem to offer similar benefits because they were dense, typically substantial in size relative to the cordgrass strips, and often had small patches of tall cordgrass interspersed throughout. Nevertheless, it is clear that needlerush does not provide high-quality habitat for Marsh Wrens. Marsh Wrens avoid upland edges where needlerush is commonly found (Nuse et al. 2015; Schwarzer, unpublished manuscript), and occupancy and densities of Marsh Wrens were both negatively correlated with needlerush in salt marsh throughout northeastern Florida (Schwarzer, unpublished manuscript). Furthermore, nest survival rates declined as the amount of needlerush increased at both the nest-site and the natalpatch scale (Cox et al., in press). The combined evidence suggests that Marsh Wrens avoid needlerush because it reduces their demographic performance at multiple life stages.

A meta-analysis of the avian literature suggests that transmitters can have a small negative effect on survival (Barron et al. 2010), and we acknowledge that additional sources of bias may have contributed to the low rates of postfledging survival we observed. First, our research activities did result in some nestlings prematurely fledging at the time of tagging, and it is possible that our survival estimates are biased somewhat low because the birds fledged at a smaller size and younger age than they otherwise would have. However, we force fledged only a small number of nestlings during our study ( 35 of $262 ; 13 \%$ ), and we did not observe any tagged bird leave a nest immediately after we put it back in. Furthermore, force-fledged birds were surprisingly fast, adept climbers, and some even swam across tidal creeks to escape the potential danger we posed. These observations, combined with the fact that the birds could quickly find shelter in any number of nearby dummy nests or quickly return to the natal nest, i.e., force fledging in this system is temporary, suggest to us that the effect of force fledging birds on survival was likely minimal, as has been observed elsewhere (Streby et al. 2013). Second, it is possible that we confounded dispersal events and lost or broken transmitters with mortality events. We think it is unlikely we missed dispersed birds because we repeatedly performed multiple extensive, expanding circular searches $(>1 \mathrm{~km}$ radius from the last known location) in the nearby marsh and failed to relocate any birds that had initially disappeared. In addition, tagged birds that disappeared usually did so within $10 \mathrm{~d}$, and the movements of tagged birds and of family groups we were tracking during that time were usually extremely limited, i.e., within $50 \mathrm{~m}$ of the nest. We recovered fewer postmortality carcasses and transmitters than most studies, and we acknowledge that it is possible we classified some birds as dead when in fact the transmitters either failed or were shed. However, there were only 6 cases in which we encountered aggressive adults (indicating that some of their young were still alive) but failed to resight the tagged fledgling. It is possible that some of these birds were alive, but in each of these cases, we were able to resight untagged siblings, and given the high overall mortality rates, we think it is reasonable to assume the tagged birds died.

Compared to other studies of passerines, which face similar challenges, the survival of fledgling Marsh Wrens was among the lowest reported in the literature (Cox et al. 2014). Why survival was so low remains unclear because we had limited opportunity to identify the causes of fledgling mortality. Nevertheless, predation was a substantial cause of nest failure at our study sites (Cox et al., in press), and the putative nest predators (primarily rats and mink) are likely also threats to altricial fledglings with limited flight capabilities that occupied the same habitat as the nests and sometimes occupied the nests themselves.

Nest survival for Marsh Wrens at our study sites was also low $(10 \%$; $95 \%$ CI: $0.04,0.18$; Cox et al., in press $)$. The low rates of both nest and postfledging survival indicate that adult survival and/or renesting rates would have to be quite high for northeastern Florida to host a stable or growing population. We failed to quantify seasonal nesting effort for most territories, but the maximum number of nest attempts we observed was four (Schwarzer, unpublished data), which is not atypical for passerine birds and less than has been reported for other species (Grzybowski and Pease 2005). It is possible that adult survival is relatively high because Marsh Wrens are sedentary and live in a mild climate and thus avoid the pulse of mortality birds face during migration (Sillett and Holmes 2002). Furthermore, recent point counts demonstrated that Marsh Wrens occupy a similar range at greater raw densities than a count performed in 2000 (Schwarzer, unpublished manuscript), though the different methods used require a cautious interpretation of that comparison. If the population did remain stable between 2000 and 2015, the range contraction prior to then may not have occurred because of a poor demographic performance of remaining populations, but instead because of a contraction of available habitat via a suite of threats related to climate change, e.g., mangrove intrusion, marsh subsidence, and sea level rise; and development, e.g., docks and dredged channels. However, absent immigration, this scenario would likely require high adult survivorship compared with other passerines in North America (annual survival of most species is $<0.7$; Muñoz et al. 2018), and even the most conservative interpretation of our demographic data would suggest that the breeding performance of the Marsh Wrens in our study area is low.

\section{MANAGEMENT IMPLICATIONS}

Identification, monitoring, and protection of northeastern Florida's remaining cordgrass-dominated marshes should be a priority because survival of fledging birds and of nests (Cox et al., in press) is positively associated with tall-form cordgrass. The ecological value of these marshes should be considered when reviewing permitting requests for upland development, docks, dredging, and other activities known to influence salt marshes. The occurrence of needlerush increases as water salinity declines and elevation increases (Stout 1984), so activities that affect these factors should be carefully evaluated. Estimation of adult survival of Marsh Wrens via a mark-resight study would provide the data needed to understand the degree to which the low rates of nest and postfledging survival we observed have contributed to the species'long-term population decline. Such a study could be done relatively inexpensively on an annual basis but would take 5 or more years to produce the desired results. That our demographic data conflict to some degree with the seemingly stable population trend over the past $15 \mathrm{yr}$ indicates that continued monitoring is warranted. 
Avian Conservation and Ecology 14(2): 19

Responses to this article can be read online at:

http://www.ace-eco.org/issues/responses.php/1472

\section{Acknowledgments:}

Funding for this study was provided by Florida's State Wildlife Grant program (grant F14AF00892 [T-35] and the Non-Game Trust Fund). We thank R. Chicalo, J. Brisbane, S. Jeffreys, L. Mengak, R. Rhodes, and L. Evans for their help in the field. We thank B. Bankovich for her assistance with GIS. L. Brown, E. Ragheb, and R. Boughton provided excellent feedback on earlier versions of this manuscript. We also thank C. Elphick and an anonymous reviewer whose friendly and informative comments greatly improved the manuscript. All applicable ethical guidelines for the use of birds in research have been followed, including those presented in the Ornithological Council's Guidelines to the Use of Wild Birds in Research. Capture and banding of birds was authorized under permit \#21980 issued by the U.S. Fish and Wildlife Service's Bird Banding Laboratory.

\section{LITERATURE CITED}

Anders, A. D., J. Faaborg, and F. R. Thompson III. 1998. Postfledging dispersal, habitat use, and home-range size of juvenile Wood Thrushes. Auk 115:349-358. https://doi. org/10.2307/4089193

Ausprey, I. J., and A. D. Rodewald. 2011. Postfledging survivorship and habitat selection across a rural-to-urban landscape gradient. Auk 128:293-302. https://doi.org/10.1525/ auk.2011.10158

Balogh, A. L., T. B. Ryder, and P. P. Marra. 2011. Population demography of Gray Catbirds in the suburban matrix: sources, sinks and domestic cats. Journal of Ornithology 152:717-726. https://doi.org/10.1007/s10336-011-0648-7

Barron, D. G., J. D. Brawn, and P. J. Weatherhead. 2010. Metaanalysis of transmitter effects on avian behaviour and ecology. Methods in Ecology and Evolution 1:180-187. https://doi. org/10.1111/j.2041-210X.2010.00013.x

Bayard, T. S., and C. Elphick. 2011. Planning for sea-level rise: quantifying patterns of Saltmarsh Sparrow (Ammodramus caudacutus) nest flooding under current sea-level conditions. Auk 128:393-403. https://doi.org/10.1525/auk.2011.10178

Burnham, K. P., and D. R. Anderson. 2002. Model selection and multimodel inference: a practical information-theoretic approach. Springer, New York, New York, USA.

Chicalo, R. M., A. Schwarzer, and W. A. Cox. 2019. Observations on the use of dummy nests by fledgling Worthington's Marsh Wrens (Cistothorus palustris griseus). Wilson Journal of Ornithology 131:396-398. https://doi.org/10.1676/18-87

Cox, W. A., A. C. Schwarzer, B. Tornwall, and R. Chicalo. In press. Tide and habitat features affect salt marsh songbird nest survival in northeast Florida. Endangered Species Research.

Cox, W. A., F. R. Thompson III, A. S. Cox, and J. Faaborg. 2014. Post-fledging survival in passerine birds and the value of post- fledging studies to conservation. Journal of Wildlife Management 78:183-193. https://doi.org/10.1002/jwmg.670

Cox, W. A., F. R. Thompson III, J. L. Reidy, and J. Faaborg. 2013. Temperature can interact with landscape factors to affect songbird productivity. Global Change Biology 19:1064-1074. https://doi.org/10.1111/gcb.12117

Crooks, K. R., M. A. Sanjayan, and D. F. Doak. 1998. New insights on cheetah conservation through demographic modeling. Conservation Biology 12:889-895. https://doi.org/10.1111/ j.1523-1739.1998.97054.x

Crouse, D. T., L. B. Crowder, and H. Caswell. 1987. A stage-based population model for loggerhead sea turtles and implications for conservation. Ecology 68:1412-1423. https://doi.org/10.2307/1939225

Donovan, T. M., and F. R. Thompson III. 2001. Modeling the ecological trap hypothesis: a habitat and demographic analysis for migrant songbirds. Ecological Applications 11:871-882. https://doi.org/10.1890/1051-0761(2001)011[0871:MTETHA]2.0. $\mathrm{CO} ; 2$

Eng, M. L., B. J. M. Stutchbury, D. M. Burke, and K. A. Elliott. 2011. Influence of forest management on pre- and post-fledging productivity of a Neotropical migratory songbird in a highly fragmented landscape. Canadian Journal of Forest Research 41:2009-2019. https://doi.org/10.1139/x11-119

Florida Fish and Wildlife Conservation Commission (FWC). 2012. Florida's Wildlife Legacy Initiative: Florida's State Wildlife Action Plan. FWC, Tallahassee, Florida, USA.

Florida Fish and Wildlife Conservation Commission (FWC). 2013. A Species Action Plan for Four Saltmarsh Songbirds. FWC, Tallahassee, Florida, USA.

Florida Fish and Wildlife Conservation Commission (FWC). 2016. Florida's Imperiled Species Management Plan. FWC, Tallahassee, Florida, USA.

Florida Fish and Wildlife Conservation Commission (FWC) and Florida Natural Areas Inventory. 2016. Cooperative land cover version 3.2. FWC, Tallahassee, Florida, USA.

Fox, J., and G. Monette. 1992. Generalized collinearity diagnostics. Journal of the American Statistical Association 87:178-183. https://doi.org/10.1080/01621459.1992.10475190

Gebhardt-Henrich, S. G., and A. J. Van Noordwijk. 1991. Nestling growth in the Great Tit I. Heritability estimates under different environmental conditions. Journal of Evolutionary Biology 4:341-362. https://doi.org/10.1046/j.1420-9101.1991.4030341. $\mathrm{x}$

Grzybowski, J. A., and C. M. Pease. 2005. Renesting determines seasonal fecundity in songbirds: what do we know? What should we assume? Auk 122:280-291. https://doi.org/10.1093/auk/122.1.280

Hightower, J. N., J. D. Carlisle, and A. D. Chalfoun. 2018. Nest mortality of sagebrush songbirds due to a severe hailstorm. Wilson Journal of Ornithology 130:561-567. https://doi. org/10.1676/17-025.1

Hovick, T. J., J. R. Miller, R. R. Koford, D. M. Engle, and D. M. Debinski. 2011. Postfledging survival of Grasshopper Sparrows in grasslands managed with fire and grazing. Condor 113:429-437. https://doi.org/10.1525/cond.2011.100135 
Hunter E. A. 2017. How will sea-level rise affect threats to nesting success for Seaside Sparrows? Condor 119:459-468. https://doi. org/10.1650/CONDOR-17-11.1

Kale, H. W., II. 1965. Ecology and bioenergetics of the Long-billed Marsh Wren Telmatodytes palustris griseus (Brewster) in Georgia salt marshes. Publications of the Nuttall Ornithological Club No. 5. Nuttall Ornithological Club, Cambridge, Massachusetts, USA.

Kale, H. W., II. 1996. Marsh Wrens. Pages 602-607 in J. A. Rodgers, Jr., H. W. Kale II, and H. T. Smith, editors. Rare and endangered biota of Florida. University Press of Florida, Gainesville, Florida, USA.

King, J. R. 1973. Energetics of reproduction in birds. Pages 78-107 in D. S. Farner, editor. Breeding biology of birds. National Academy of Sciences, Washington, D.C., USA.

Kroodsma, D. E., and J. Verner. 2013. Marsh Wren (Cistothorus palustris), version 2.0. In A. F. Poole, editor. The birds of North America. Cornell Lab of Ornithology, Ithaca, New York, USA. https://doi.org/10.2173/bna.308

Lele, S. R., J. L. Keim, and P. Solymos. 2017. ResourceSelection: resource selection (probability) functions for use-availability data. Rpackage 0.3-2. R Foundation for Statistical Computing, Vienna, Austria. [online] URL: https://cran.r-project.org/web/packages/ ResourceSelection/index.html

Leonard, M. L., and J. Picman. 1987. Nesting mortality and habitat selection by Marsh Wrens. Auk 104:491-495. https://doi. org/10.2307/4087548

Magrath, R. D. 1991. Nestling weight and juvenile survival in the Blackbird, Turdus merula. Journal of Animal Ecology 60:335-351. https://doi.org/10.2307/5464

Marra, P. P., E. B. Cohen, S. R. Loss, J. E. Rutter, and C. M. Tonra. 2015. A call for full annual cycle research in animal ecology. Biology Letters 11:20150552. https://doi.org/10.1098/rsbl.2015.0552

Martin, T. E., and G. R. Geupel. 1993. Nest-monitoring plots: methods for locating nests and monitoring success. Journal of Field Ornithology 64:507-519.

Muñoz, A. P., M. Kéry, P. V. Martins, and G. Ferraz. 2018. Age effects on survival of Amazon forest birds and the latitudinal gradient in bird survival. Auk 135:299-313. https://doi. org/10.1642/AUK-17-91.1

National Oceanic and Atmospheric Administration (NOAA). 2018. Tides and currents. NOAA, Silver Spring, Maryland, USA. [online] URL: https://tidesandcurrents.noaa.gov/

National Oceanic and Atmospheric Administration (NOAA), National Centers for Environmental Information (NCEI). 2018. Climate data online search. NCEI, Asheville, North Carolina, USA. [online] URL: https://www.ncdc.noaa.gov/cdo-web/ search

NeSmith, C. C., and S. S. Jue. 2003. Resurvey of the distribution and status of MacGillivray's Seaside Sparrow and Worthington's Marsh Wren in Florida. Florida Fish and Wildlife Conservation Commission, Tallahassee, Florida, USA.
Nuse, B. L., R. J. Cooper, and E. A. Hunter. 2015. Prospects for predicting changes to coastal wetland bird populations due to accelerated sea level rise. Ecosphere 6:1-23. https://doi. org/10.1890/ES15-00385.1

Pollock, K. H., S. R. Winterstein, C. M. Bunck, and P. D. Curtis. 1989. Survival analysis in telemetry studies: the staggered entry design. Journal of Wildlife Management 53:7-15. https://doi. org/10.2307/3801296

Post, W. 1981. The influence of rice rats Oryzomys palustris on the habitat use of the Seaside Sparrow Ammospiza maritima. Behavioral Ecology and Sociobiology 9:35-40. https://doi. org/10.1007/BF00299850

R Development Core Team. 2017. R: a language and environment for statistical computing. R Foundation for Statistical Computing, Vienna, Austria. [online] URL: https://www.R-project.org/

Rush, S. A., and B. J. M. Stutchbury. 2008. Survival of fledgling Hooded Warblers (Wilsonia citrina) in small and large forest fragments. Auk 125:183-191. https://doi.org/10.1525/auk.2008.125.1.183

Shaffer, T. L. 2004. A unified approach to analyzing nest success. Auk 121:526-540. https://doi.org/10.1093/auk/121.2.526

Shaffer, T. L., and F. R. Thompson III. 2007. Making meaningful estimates of nest survival with model-based methods. Pages 84-95 in S. L. Jones and G. R. Geupel, editors. Beyond Mayfield: measurements of nest-survival data. Studies in Avian Biology, No. 34. Cooper Ornithological Society, Camarillo, California, USA.

Shipley, A. A., M. T. Murphy, and A. H. Elzinga. 2013. Residential edges as ecological traps: postfledging survival of a ground-nesting passerine in a forested urban park. $A u k$ 130:501-511. https://doi.org/10.1525/auk.2013.12139

Sillett, T. S., and R. T. Holmes. 2002. Variation in survivorship of a migratory songbird throughout its annual cycle. Journal of Animal Ecology 71:296-308. https://doi.org/10.1046/ j.1365-2656.2002.00599.x

Stout, J. P. 1984. Ecology of irregularly flood salt marshes of northeastern Gulf of Mexico: a community profile. Biological report 85(7.1). U.S. Fish and Wildlife Service, Washington, D.C., USA.

Streby, H. M., T. L. McAllister, S. M. Peterson, G. R. Kramer, J. A. Lehman, and D. E. Andersen. 2015a. Minimizing marker mass and handling time when attaching radio-transmitters and geolocators to small songbirds. Condor 117:249-255. https://doi. org/10.1650/CONDOR-14-182.1

Streby, H. M., S. M. Peterson, G. R. Kramer, and D. E. Andersen. 2015b. Post-independence fledgling ecology in a migratory songbird: implications for breeding-grounds conservation. Animal Conservation 18:228-235. https://doi.org/10.1111/acv.12163

Streby, H. M., S. M. Peterson, J. A. Lehman, G. R. Kramer, K. J. Iknayan, and D. E. Andersen. 2013. The effects of force-fledging and premature fledging on the survival of nestling songbirds. Ibis 155:616-620. https://doi.org/10.1111/ibi.12051

Streby, H. M., J. M. Refsnider, and D. E. Andersen. 2014. Redefining reproductive success in songbirds: moving beyond the 
nest success paradigm. Auk 131:718-726. https://doi.org/10.1642/ AUK-14-69.1

Suedkamp Wells, K. M., M. R. Ryan, J. J. Millspaugh, F. R. Thompson III, and M. W. Hubbard. 2007. Survival of postfledging grassland birds in Missouri. Condor 109:781-794. https://doi.org/10.1093/condor/109.4.781

Venables, W. N., and B. D. Ripley. 2002. Modern applied statistics with $S$. Fourth edition. Springer, New York, New York, USA. https://doi.org/10.1007/978-0-387-21706-2

Verner, J., and G. H. Engelsen.1970. Territories, multiple nest building, and polygyny in the Long-billed Marsh Wren. Auk 87:557-567. https://doi.org/10.2307/4083798

Vitz, A. C., and A. D. Rodewald. 2006. Can regenerating clearcuts benefit mature-forest songbirds? An examination of postbreeding ecology. Biological Conservation 127:477-486. https:// doi.org/10.1016/j.biocon.2005.09.011

Wilkin, T. A., L. E. King, and B. C. Sheldon. 2009. Habitat quality, nestling diet, and provisioning behaviour in Great Tits Parus major. Journal of Avian Biology 40:135-145. https://doi. org/10.1111/j.1600-048X.2009.04362.x

Sponsored by the Society of Canadian Ornithologists and Bird Studies Canada

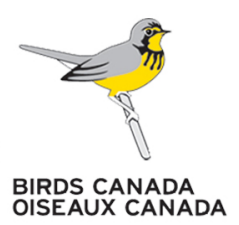

